\title{
Effect of introducing antenatal diagnosis on reproductive behaviour of families at risk for thalassaemia major
}

\author{
B MODELL, R H T WARD, D V I FAIRWEATHER
}

\section{Summary and conclusions}

Families who were at risk of producing a child with thalassaemia major were studied to determine the sequential effects on their reproductive behaviour of knowing the risk and, subsequently, of knowing that antenatal diagnosis was available. Knowing the risk caused them virtually to stop reproduction and to seek termination of $70 \%$ of pregnancies, most of which were accidental. The introduction of antenatal diagnosis in 1975 permitted the resumption of nearly normal reproduction by at-risk families, with fewer than $30 \%$ of pregnancies being terminated for thalassaemia major.

All couples at risk for thalassaemia major should be detected and counselled before they produce an affected child; responsibility for either choosing or refusing antenatal diagnosis should be theirs alone.

\section{Introduction}

As prevention of severe congenital disease by antenatal diagnosis and termination of affected pregnancies is becoming increasingly accepted in Western society, its effects on the at-risk family and community need to be documented. A clear-cut opportunity for measuring some of the social effects of this preventive approach for a severe disease with a high incidence in a defined population was provided by the introduction of antenatal diagnosis for thalassaemia major among the large Cypriot community of north-east London. ${ }^{1}$

The wide distribution and great prevalence of $\beta$-thalassaemia major in the Middle and Far East make it the most common of all inherited human lethal conditions. ${ }^{2}$ It is transmitted as a Mendelian recessive; hence heterozygotes are symptomless but can be reliably detected by blood tests. When two heterozygotes marry the risk of producing an affected child is one in four in each pregnancy. Untreated, the patients usually die of anaemia between 2 and 6 years of age. Effective treatment consists of regular blood transfusions and intensive administration of the iron-chelating agent desferrioxamine by subcutaneous infusion for eight to 12 hours nightly. ${ }^{3-5}$ Among Greek and Turkish Cypriots the prevalence of heterozygotes is about $15 \%$, the prevalence of at-risk marriages $2 \%$, and the birth rate of homozygous infants five per thousand. ${ }^{6}{ }^{7}$

In Britain there are about 300 patients with thalassaemia major, two-thirds of whom are of Cypriot origin and one-third of Indian or Pakistani origin. Each year about 15 children with the disease are born in Britain-that is, some 60 pregnancies are at risk yearly.$^{8}$ During the past four years prevention of the disease by prospective genetic counselling and antenatal diagnosis of at-risk pregnancies has been offered to couples at risk. The feasibility of this approach depends on the accurate haematological diagnosis of couples of carriers even before they have had an affected child, ${ }^{2}$ the ability to diagnose homozygous fetuses by using microsamples of fetal blood, ${ }^{910}$ and the development

University College Hospital Medical School, London WC1E 6DH B MODELL, MB, PHD, honorary senior lecturer in paediatrics R H T WARD, MA, MRCOG, senior lecturer in obstetrics and gynaecology D V I FAIRWEATHER, MD, FRCOG, professor of obstetrics and gynaecology of obstetric methods of fetal blood sampling before the 20th week of gestation. ${ }^{11-13}$ The real usefulness of antenatal diagnosis to the population concerned, however, depends on other factors, such as the degree of awareness of the risk by health workers in the community, and by the community itself; the identification and accurate counselling of at-risk couples; and their response to understanding the risk, availability, and limitations of antenatal diagnosis.

We describe the effect in the first instance of knowing the risk, and subsequently of knowing that antenatal diagnosis is available, on the reproductive behaviour of at-risk couples in Britain.

\section{Methods}

From December 1974 to December 1979 we performed over 300 antenatal diagnoses for thalassaemia major and other haemoglobinopathies. ${ }^{14}$ This report is concerned with 77 of these that were done for 61 families resident in England who were available for complete follow-up, had open access to an antenatal diagnostic service, and shared the same environment as the native British.

\section{COLLECTION OF INFORMATION ON COUNSELLED AT-RISK COUPLES}

We were kept aware of the number of pregnant at-risk couples detected and counselled, even when they were not referred for antenatal diagnosis, because even if an at-risk couple rejected antenatal diagnosis or were detected too late in pregnancy we were usually asked to provide a neonatal diagnosis from cord blood.

\section{DETECTION OF AT-RISK COUPLES}

The couples found themselves to be at risk (a) by producing an affected child; $(b)$ as a result of maternal screening in the antenatal clinic (blood samples from heterozygotes show microcytosis and contain an increased proportion of haemoglobin $\mathrm{A}_{2}$; in such cases the husband is also tested); and (c) by premarital or intramarital testing before they undertook any pregnancies.

\section{CONTENT OF COUNSELLING}

Counselling was non-directive and entailed discussing with the couple the one-in-four chance of having an affected child in each pregnancy; the clinical manifestations and improving prognosis of thalassaemia major; the $7-10 \%$ risk of losing the pregnancy as a result of fetal blood sampling ${ }^{13}$; and the method and risks of inducing midtrimester abortion by intra-amniotic injection of prostaglandin.

\section{COLLECTION AND ANALYSIS OF DATA}

The obstetric history taken included the date of marriage, year and outcome of each pregnancy, year when the couple found themselves at risk, and year and circumstances under which they discovered that antenatal diagnosis was available.

We divided each couple's married life into the number of whole married years passed in each of the following four phases, and recorded the number of pregnancies, terminations of pregnancy, and healthy children and children with thalassaemia born in each phase. Phase 1 (years when they did not know their risk) included the year of marriage to the year when they discovered their risk. Phase 2 (years when they knew their risk but antenatal diagnosis was not available) included the 
year after they discovered their risk to the year before they discovered that antenatal diagnosis was available. Phase 3 (years when they knew both their risk and that antenatal diagnosis was available) included the year when they first heard of antenatal diagnosis to the end of 1979. Phase 4 (pregnancies started when they did not know the risk, but counselling given and antenatal diagnosis offered): 24 at-risk couples were discovered in the antenatal clinic, so the index pregnancy had been started in ignorance but had to be completed knowing the risk. Six couples had already had normal children in ignorance of their risk before antenatal diagnosis was available (phase 1). The year in which they were informed of their risk and decided what to do about the current pregnancy was counted as phase 4 , and subsequent years as phase 3. Eighteen mothers were primigravidae who had married after antenatal diagnosis became generally available (1976). Their years from marriage to counselling were counted as phase 4 , and subsequent years as phase 3 .

All pregnancies started before November 1979 were included. Of 182 pregnancies, $12(7 \%)$ ended in early spontaneous abortion: only the 170 continuing pregnancies were counted. All children not suffering from thalassaemia major are described as "healthy." All parents were British nationals. Most were of Greek Cypriot or Turkish Cypriot ancestry and are grouped together as Cypriots; a smaller group either originated from or had ancestors originating from the north-western part of the Indian subcontinent (Indians, Pakistanis, and East African Asians) and are referred to as "Indians" in reference to their continental origin.

\section{Results}

The number of at-risk couples identified yearly rose from four in 1976 to 25 in 1979. Since the theoretical number of at-risk pregnancies yearly for the whole of Britain is 60, at least half the at-risk couples must be passing through antenatal clinics uncounselled.

\section{CHOICES OF COUNSELLED AT-RISK COUPLES}

Table I shows how the couples were identified and their choices after counselling. Ninety-four per cent of Cypriots and only $59 \%$ of Indians requested antenatal diagnosis (table II). The Cypriots are a uniform cultural group, ${ }^{15}$ but the Indian families fell into four groups (table III). The numbers are small, but interest appears to have been lowest among first-generation Indians of rural origin.

Indians in general experienced much more difficulty than Cypriots in deciding what to do. There was serious disagreement between the parents in three cases. One couple refused antenatal diagnosis in the first pregnancy but wanted it in the second, one couple requested it in the first pregnancy but not in the second, and one mother chose to

TABLE I-How couples of heterozygotes for $\beta$-thalassaemia discovered their risk of producing a child with thalassaemia major

\begin{tabular}{|c|c|c|c|}
\hline & $\begin{array}{l}\text { No of } \\
\text { couples }\end{array}$ & $\begin{array}{l}\text { No } \\
\text { requesting } \\
\text { antenatal } \\
\text { diagnosis }\end{array}$ & $\begin{array}{l}\text { No } \\
\text { rejecting } \\
\text { antenatal } \\
\text { diagnosis }\end{array}$ \\
\hline $\begin{array}{l}\text { By having a child with thalassaemia major } \\
\text { In the antenatal clinic during pregnancy } \\
\text { By premarital or intramarital testing }\end{array}$ & $\begin{array}{l}36 \\
31\end{array}$ & $\begin{array}{l}30 \\
23\end{array}$ & $\begin{array}{l}6 \\
8\end{array}$ \\
\hline (parents' initiative) $\quad . \quad$. . & 8 & 8 & \\
\hline Total & 75 & 61 & 14 \\
\hline
\end{tabular}

TABLE II-Ethnic origins and choices of counselled couples at risk of producing offspring with thalassaemia major

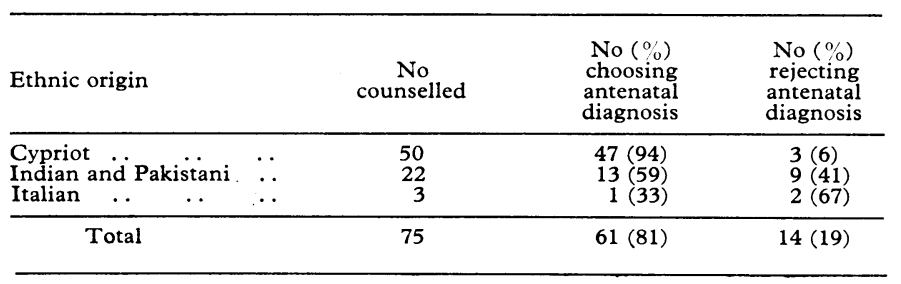

TABLE III-Choices of "Indian" couples in relation to social group

\begin{tabular}{lcccc}
\hline & $\begin{array}{c}\text { No } \\
\text { counselled }\end{array}$ & $\begin{array}{c}\text { No } \\
\text { choosing } \\
\text { antenatal } \\
\text { diagnosis }\end{array}$ & $\begin{array}{c}\text { No } \%) \\
\text { rejecting } \\
\text { antenatal } \\
\text { diagnosis }\end{array}$ \\
\hline $\begin{array}{c}\text { Doctors .. . . } \\
\text { East African Asians }\end{array}$ & $\cdots$ & 3 & 3 & $4(36)$ \\
$\begin{array}{l}\text { Rural Indians: } \\
\text { First generation }\end{array}$ & $\ldots$ & 11 & 7 & $5(71)$ \\
Second generation & $\cdots$ & 7 & 1 & $9(41)$ \\
\hline \multicolumn{1}{c}{ Total } & & 22 & 13 & \\
\hline
\end{tabular}

continue her pregnancy despite a diagnosis of thalassaemia major. In the larger Cypriot group only one such change of mind occurred, one mother choosing antenatal diagnosis in her fourth pregnancy but not in her fifth, on religious grounds.

\section{REPRODUCTIVE BEHAVIOUR OF COUPLES MAKING USE OF} ANTENATAL DIAGNOSIS

The number of pregnancies started and terminated in each of the four phases by couples who chose antenatal diagnosis provides an objective measure of these families' reactions to thalassaemia major and the introduction of antenatal diagnosis (table IV).

The pregnancy rate in phase 1 (ignorant of risk) was one per 2.6 married years because Cypriots, though satisfied with small families, begin reproducing very soon after marriage. Only one pregnancy was terminated. Only $43 \%$ (instead of $75 \%$ ) of the children were healthy because so many couples discovered their risk by producing an affected child. After discovery of their risk the pregnancy rate fell by half: most of these pregnancies were accidental, and $70 \%$ were terminated because of the risk of thalassaemia major. In this phase the families produced only one healthy child per 48 married years.

Twenty-four couples were detected in the antenatal clinic during a pregnancy started in ignorance of risk, and most accepted the offer of antenatal diagnosis. This group, being counselled during pregnancy, had limited options : free choice was exercised only in the fourth group.

Forty-seven couples undertook pregnancies knowing both their risk and what was entailed in antenatal diagnosis: 16 of them had already undergone antenatal diagnosis once or even twice (four couples). The pregnancy rate was one per 2.4 married years. Antenatal diagnosis was requested in all but one pregnancy, 35\% of pregnancies were terminated ( $7 \%$ losses due to the procedure), and $97 \%$ of the children were healthy (one misdiagnosis). The birth rate of healthy children was one per 3.9 married years.

Table V shows the behaviour of 25 couples who had spent a part of their married life in each of phases 1-3 and had all had one or more children with thalassaemia major. The knowledge of the inheritance of thalassaemia major caused them virtually to stop reproduction, while the introduction of antenatal diagnosis permitted the resumption of nearly normal reproduction. Table VI shows that the reproductive behaviour of the 24 couples without any affected children, who were detected in the antenatal clinic, did not differ greatly from that of the "experienced" group with an affected child. Of the 12 such young couples who have had time to start further pregnancies, eight have initiated 10 pregnancies; they have requested antenatal diagnosis again in all, and three pregnancies were terminated because of thalassaemia major.

\section{Discussion}

Our results show an appreciable difference between Indians and Cypriots in the acceptability of genetic counselling and antenatal diagnosis for thalassaemia: there was an overwhelming demand for this service from the British Cypriot community and a resultant reduction in the number of normal pregnancies terminated. Unfortunately, it appears that antenatal diagnosis is being offered to under half the at-risk pregnant mothers who might wish to know it is available. One reason for this is a low index of suspicion for the heterozygotes, since doctors generally do not realise that while homozygotes for most inherited diseases are uncommon, heterozygotes may be very common: for instance, a north London GP may have 30 heterozygotes for thalassaemia 
TABLE IV-Reproductive behaviour of couples choosing antenatal diagnosis for thalassaemia (whole group; 59 couples)*

\begin{tabular}{|c|c|c|c|c|c|c|c|}
\hline & $\begin{array}{l}\text { No of } \\
\text { couples }\end{array}$ & $\begin{array}{c}\text { Total } \\
\text { years } \\
\text { married }\end{array}$ & $\begin{array}{c}\text { Married } \\
\text { years per } \\
\text { pregnancy }\end{array}$ & $\begin{array}{l}\% \text { choosing } \\
\text { antenatal } \\
\text { diagnosis }\end{array}$ & $\begin{array}{c}\% \text { of } \\
\text { pregnancies } \\
\text { terminated }\end{array}$ & $\begin{array}{c}\% \text { of } \\
\text { children } \\
\text { healthy }\end{array}$ & $\begin{array}{c}\text { Married } \\
\text { years per } \\
\text { healthy child }\end{array}$ \\
\hline $\begin{array}{l}\text { Pregnancies started and completed not knowing risk } \\
\text { Pregnancies started knowing risk but antenatal diagnosis no }\end{array}$ & 40 & 145 & $2 \cdot 6$ & 0 & $1 \cdot 4$ & 43 & $6 \cdot 3$ \\
\hline $\begin{array}{l}\text { available } \\
\text { Pregnancies started not knowing risk, but couples }\end{array}$ & 26 & 95 & $4 \cdot 8$ & 0 & 70 & 33 & 48.0 \\
\hline $\begin{array}{l}\text { counselled and offered antenatal diagnosis } \\
\text { Pregnancies started knowing risk and that antenatal }\end{array}$ & 24 & 49 & $2 \cdot 0$ & 95 & 27 & 100 & $3 \cdot 1$ \\
\hline diagnosis available $\ldots \quad \ldots \quad \ldots \quad \ldots \quad \ldots$ & 47 & 137 & $2 \cdot 4$ & 98 & 35 & 97 & 3.9 \\
\hline
\end{tabular}

*Two of the 61 families choosing antenatal diagnosis were omitted as atypical: one was Italian and the other, having been infertile for 17 years, introduced a bias into the calculations.

TABLE $\mathrm{v}-$ Reproductive behaviour of couples choosing antenatal diagnosis for thalassaemia (25 couples passing through all phases 1-3)

\begin{tabular}{|c|c|c|c|c|c|c|}
\hline & $\begin{array}{l}\text { Total } \\
\text { years } \\
\text { married }\end{array}$ & $\begin{array}{l}\text { Married } \\
\text { years per } \\
\text { pregnancy }\end{array}$ & $\begin{array}{l}\% \text { choosing } \\
\text { antenatal } \\
\text { diagnosis }\end{array}$ & $\begin{array}{c}\% \text { of } \\
\text { pregnancies } \\
\text { terminated }\end{array}$ & $\begin{array}{l}\text { \% of } \\
\text { children } \\
\text { healthy }\end{array}$ & $\begin{array}{l}\text { Married } \\
\text { years per } \\
\text { healthy child }\end{array}$ \\
\hline $\begin{array}{l}\text { Pregnancies started and completed not knowing risk } \\
\text { Pregnancies started knowing risk, but antenatal diagnosis not available } \\
\text { Pregnancies started knowing risk and that antenatal diagnosis available }\end{array}$ & $\begin{array}{l}86 \\
93 \\
96\end{array}$ & $\begin{array}{l}2 \cdot 4 \\
4 \cdot 9 \\
3 \cdot 0\end{array}$ & $\begin{array}{r}0 \\
0 \\
97\end{array}$ & $\begin{array}{r}0 \\
68 \\
34\end{array}$ & $\begin{array}{l}36 \\
33 \\
96\end{array}$ & $\begin{array}{r}6 \cdot 6 \\
47 \cdot 0 \\
4 \cdot 6\end{array}$ \\
\hline
\end{tabular}

TABLE VI-Reproductive behaviour of couples choosing antenatal diagnosis for thalassaemia (24 couples without an affected child, detected during pregnancy)

\begin{tabular}{|c|c|c|c|c|c|c|c|}
\hline & $\begin{array}{c}\text { No of } \\
\text { couples }\end{array}$ & $\begin{array}{c}\text { Total } \\
\text { years } \\
\text { married }\end{array}$ & $\begin{array}{c}\text { Married } \\
\text { years per } \\
\text { pregnancy }\end{array}$ & $\begin{array}{l}\% \text { choosing } \\
\text { antenatal } \\
\text { diagnosis }\end{array}$ & $\begin{array}{c}\% \text { of } \\
\text { pregnancies } \\
\text { terminated }\end{array}$ & $\begin{array}{l}\text { \% of } \\
\text { children } \\
\text { healthy }\end{array}$ & $\begin{array}{c}\text { Married } \\
\text { years per } \\
\text { healthy child }\end{array}$ \\
\hline $\begin{array}{l}\text { Pregnancies started and completed not knowing risk } \\
\text { Pregnancies started not knowing risk, but counselled and }\end{array}$ & 6 & 39 & 3.5 & 0 & 18 & 100 & $4 \cdot 3$ \\
\hline $\begin{array}{l}\text { offered antenatal diagnosis } \\
\text { Pregnancies started knowing risk and that antenatal }\end{array}$ & 24 & 49 & $2 \cdot 2$ & 95 & 27 & 100 & $3 \cdot 1$ \\
\hline $\begin{array}{llllll}\text { diagnosis available } & . & \ldots & \ldots & \ldots & \ldots\end{array}$ & 12 & 19 & 1.9 & 100 & 30 & 100 & $2 \cdot 7$ \\
\hline
\end{tabular}

(detectable) and 100 for fibrocystic disease (now probably detectable ${ }^{16}$ ) on his list. A similar response to that reported here to prospective genetic counselling and antenatal diagnosis was reported for Tay-Sachs disease among Ashkenazi Jews in the United States, ${ }^{17}$ and parents of children with fibrocystic disease attempt to limit their families in the same way that parents of children with thalassaemia major did before antenatal diagnosis became available (C Carter, personal communication). ${ }^{18}$

The demand for antenatal diagnosis for thalassaemia means that it is necessary to detect and counsel all at-risk couples before they produce an affected child, because even if they do not choose antenatal diagnosis the responsibility for this decision should be theirs. The risk for Cypriots is high. Any pregnant Cypriot woman with $\beta$-thalassaemia trait has a one in 28 chance of delivering a child with thalassaemia major: she has a one in seven chance of being married to another heterozygote and if she is her chance of delivering a homozygous child is one in four. The risks among Indians are less well defined. Since in Britain haemoglobin is now usually measured by the Coulter $S$ machine, which also routinely measures mean cell haemoglobin and mean cell volume, preliminary screening for microcytosis is extremely easy (see appendix) and costs nothing. It is well within the range of the GP, general obstetrician, hospital doctor, antenatal nursing staff, and indeed any health worker to identify individuals in need of definitive diagnosis by estimating the proportion of $\mathrm{Hb} \mathrm{A}_{2}$, which must be done in a reliable laboratory.

Though sickle-cell anaemia may also be diagnosed reliably in heterozygotes and antenatally on fetal blood samples, the difference in demand for antenatal diagnosis for thalassaemia major (always a cause of great distress and affecting Cypriots and Indians) and sickle-cell anaemia (not always causing great distress and affecting Africans and West Indians) has been striking, the perceived risk of sickle-cell anaemia often being insufficient to offset the risk to the pregnancy of fetal blood sampling. The American experience is similar. ${ }^{10}$ Recent progress in diagnosing haemoglobinopathies by using DNA from amniotic fluid fibroblasts ${ }^{1819}$ may reduce the risk of diagnosis to that of amniocentesis, so it is now also important to detect and counsel couples heterozygous for $\mathrm{Hb} \mathrm{S}$.

\section{WHERE SHOULD SCREENING AND COUNSELLING BE DONE?}

Medical responsibility for the birth of children with avoidable congenital disease reaches its maximum in the antenatal clinic. If an affected child is born without the parents having been advised of their risk the responsibility is often thought to rest with the obstetrician. In women of the appropriate ethnic groups preliminary screening for thalassaemia trait should be done as early as possible in the antenatal clinic or preferably by the GP when pregnancy is diagnosed (or even before). Counselling at-risk couples about the one-in-four risk of having an affected child in each pregnancy is also simple, but specialist advice is needed about the nature of the disease and the problems inherent in midtrimester fetal blood sampling and termination of pregnancy.

Though screening must be done in the antenatal clinic, some couples may book too late to have the option of antenatal diagnosis, and in any case this is not the ideal way for young couples to learn that they might have a sick child, as they are called on to make hasty decisions in a state of shock. Where else should screening occur? On questioning, nearly all Cypriot couples said that people should know before they got married, in order to make their decisions about marriage and reproduction responsibly.

For a community with this attitude there are many possibilities for education and genetic counselling. Public education through newspapers and television has been successful in both England and Cyprus; parents' associations maintain a constant trickle of information: the genetics of thalassaemia is part of the biology curriculum in Cyprus and in some north London schools; information and the offer of screening through the school medical service at the time of BCG vaccination (13 years) has been considered ( $M$ Rossiter, personal communication); some 
Orthodox churches are prepared to hand out leaflets advising blood tests to couples getting married; and many family planning doctors consider genetic counselling to be part of their role. In hospital and general practice all individuals of relevant racial groups may be incidentally screened for thalassaemic microcytosis when their blood is tested for any reason, and they should receive genetic counselling. It is as important for Cypriots to know that they are not heterozygotes as that they are. If information is available at all these points individuals become aware that they themselves might be a carrier and can request testing at the nodal point in their lives (courtship, marriage, or the start of a pregnancy) when they feel the need for it. As a corollary, there should be a high degree of awareness by all health workers in communities in which diagnosable inherited disease is common so that they can all, from the health visitor to the GP and hospital doctors, give simple, accurate counselling and ensure that individuals have access to blood testing and expert advice when they want it.

The needs of Indians differ from those of Cypriots. Their cultural patterns make it unlikely that any campaign of public education and premarital genetic counselling would be beneficial, and the best option may be highly confidential screening in the antenatal clinic. Even though a high rate of rejection of the proffered information is to be expected in some areas, such as Bradford and Leeds, the obstetrician should still share this information with his patients to achieve equitable distribution of responsibility.

We gratefully acknowledge the support given to us by Sheikh Faisal and Madame Nouha Al-Hegelan and the personal generosity of Prince Sultan bin Abdulaziz of Saudi Arabia, which made this work possible. We are appreciative of the help of the many colleagues who referred patients to us, especially Dr George Marsh, Miss Ruth Coles, Dr Elizabeth Letsky, and Dr Kay Hunt. This work was supported by grants from the Sir Halley Stewart Trust, the Wellcome Trust, the Medical Research Council, and the King Abdulaziz Research Fund.

\section{Appendix}

\section{DETECTION OF THALASSAEMIA TRAIT}

The table shows the haematological characteristics of $\beta$-thalassaemia trait. Typically, $\beta$-thalassaemia trait causes pronounced microcytosis in the absence of anaemia. Since most large hospitals now use the Coulter $\mathrm{S}$ machine, automated red-cell indices are routinely available and this front-line screen for thalassaemia trait costs nothing.

Mean $( \pm 1 S D)$ haematological indices in $\beta$-thalassaemia trait *

\begin{tabular}{|c|c|c|c|}
\hline & & $\begin{array}{l}\text { Normal } \\
\text { English } \\
\text { man }\end{array}$ & $\begin{array}{c}\text { Male Cypriots } \\
\text { with } \beta \text {-thalassaemia } \\
\text { trait }\end{array}$ \\
\hline \multirow{2}{*}{ 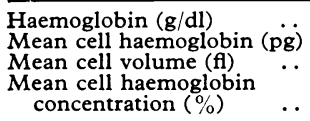 } & $\begin{array}{l}\cdots \\
\cdots\end{array}$ & $\begin{array}{l}14 \cdot 7 \pm 1 \cdot 01 \\
29 \cdot 7 \pm 1 \cdot 67 \\
87 \cdot 0 \pm 4 \cdot 7\end{array}$ & $\begin{array}{l}13 \cdot 5 \pm 1 \cdot 05 \\
21 \cdot 6 \pm 1 \cdot 8 \\
65 \cdot 0 \pm 4 \cdot 3\end{array}$ \\
\hline & .. & $34 \cdot 0 \pm 1 \cdot 04$ & $32 \cdot 8 \pm 1.01$ \\
\hline
\end{tabular}

*Values from North Middlesex Hospital (by courtesy of Dr G Marsh).

$\beta$-Thalassaemia is definitively diagnosed by finding a raised fraction of $\mathrm{Hb} \mathrm{A}_{2}$. This test is efficient if only those samples with a mean cell haemoglobin of less than $27 \mathrm{pg}$ or a mean cell volume of less than $78 \mathrm{fl}$ are analysed. Though values for $\mathrm{Hb} \mathrm{A}_{2}$ differ between laboratories, normal individuals and those with $\beta$-thalassaemia trait may usually be clearly distinguished. For example, at the North Middlesex Hospital and this hospital the normal range is $1 \cdot 8-3.2 \%$ for $\mathrm{Hb} \mathrm{A}_{2}$, while in $\beta$-thalassaemia trait the value is above $4 \%$. Results falling between 3 and $4 \%$ require further investigation.

Diagnostic problems may be created by existing severe iron deficiency (which may cause microcytosis and rarely reduces the proportion of $\mathrm{Hb} \mathrm{A}_{2}$ ), $\alpha_{1}$-thalassaemia trait, and unusual forms of thalassaemia such as $\delta \beta$-thalassaemia trait (raised $\mathrm{Hb} F$ and normal $\mathrm{Hb} \mathrm{A}_{2}$ ) or "silent" $\beta$-thalassaemia (microcytosis with a normal $\mathrm{Hb} \mathrm{A_{2 }}$ resembling $\alpha_{1}$-thalassaemia; or near-normocytosis with a raised $\mathrm{Hb} \mathrm{A}_{2}$ ). To deal with these problems the husbands of all women with appreciable microcytosis should have their blood tested, and if both partners show microcytosis that cannot be attributed simply to iron deficiency they should be referred, or blood sent, to a reliable reference centre for definitive diagnosis. Though this problem is most common among immigrants from the Mediterranean or Far East, it may also occur in one in 1000 people of traditional British stock. " "Nonspecific" microcytosis is common among children, especially those under 4 years old. The simplest approach to diagnostic difficulty in a child is to test the parents.

Booklets useful for genetic counselling of individuals who carry $\beta$-thalassaemia trait may be obtained from The United Kingdom Thalassaemia Society, 107 Nightingale Lane, London N8.

\section{References}

1 Fairweather DVI, Modell B, Berdoukas V, et al. Antenatal diagnosis of thalassaemia major. $\mathrm{Br}$ Med $\mathcal{f} 1978 ; \mathrm{i}: 350-3$

2 Weatherall DJ, Clegg JB. The thalassaemia syndromes. Oxford: Blackwell Scientific, 1972.

${ }^{3}$ Propper RD, Cooper B, Rufo RR, et al. Continuous subcutaneous infusion of desferrioxamine in patients with iron overload. N Engl f Med 1977; 297:418-23.

${ }^{4}$ Hussain MAM, Flynn DM, Green N, Hussein S, Hoffbrand AV. Subcutaneous infusion and intramuscular injection of desferrioxamine in patients with transfusional iron overload. Lancet 1976;ii:1278-80.

${ }^{5}$ Pippard MJ, Callender ST, Letsky EA, Weatherall DJ. Prevention of iron-loading in transfusion-dependent thalassaemia. Lancet 1978;i: 1178-80.

6 Modell B, Benson A, Payling-Wright CR. Incidence of $\beta$-thalassaemia trait among Cypriots in London. $\mathrm{Br}$ Med $\mathcal{F} 1972$;ii:737-8.

${ }^{7}$ Ashiotis T, Zachariadis Z, Sofroniadou K, Loukopoulos D, Stamatoyannopoulos G. Thalassaemia in Cyprus. $B r$ Med $\mathcal{F} 1973$;ii:38-40.

${ }^{8}$ Modell B. Management of thalassaemia major. Br Med Bull 1976;32: $270-6$.

- Kan YW, Trecartin RF, Golbus MS, Filly RA. Prenatal diagnosis of $\beta$-thalassaemia and sickle cell anaemia. Experience with 24 cases. Lancet $1977 ; \mathrm{i}: 269-71$.

10 Alter BP. Prenatal diagnosis of haemoglobinopathies and other haematologic diseases. F Pediatr 1979;95:501-3.

11 Hobbins JC, Mahoney MG. In utero diagnosis of haemoglobinopathies. Technic for obtaining fetal blood. N Engl f Med 1974;290:1065-8.

12 Kan YW, Valenti C, Guidotti R, Cornazza V, Rieder RF. Fetal blood sampling in utero. Lancet $1974 ; \mathrm{i}: 79-80$

13 Fairweather DVI, Ward RHT, Modell B. Obstetric aspects of midtrimester fetal blood sampling by needling or fetoscopy. $\mathrm{Br} \mathcal{F}$ Obstet and Gynaecol 1980;87:87-99.

14 Matsakis M, Berdoukas VA, Angastiniotis $M$, et al. Haematological aspects of antenatal diagnosis for haemoglobinopathies in Britain. $\mathrm{Br} \mathcal{F}$ Haematol (in press).

15 Constantinides P. Migrants and minorities in Britain. In: Watson JL, ed. Between two cultures. Oxford: Blackwell, 1977.

${ }^{16}$ Manson JC, Brock DJH. Development of quantitative immunoassay for the cystic fibrosis gene. Lancet $1980 ; \mathrm{i}: 330-1$.

17 Kaback MM, Zieger RS, Reynolds LW, Sonneborn M. Tay-Sachs disease: a model for the control of recessive genetic disorders. In: Motulsky AG, Lenz W, eds. Birth Defects. Amsterdam: Excerpta Medica, $1974: 248-61$.

18 Burton L. The family life of sick children. London and Boston: Routledge and Kegan Paul, 1975:214.

$19 \mathrm{Kan}$ YW, Dozy AM. Antenatal diagnosis of sickle-cell anaemia by DNA analysis of amniotic fluid cells. Lancet 1978;ii:910-2.

${ }^{20}$ Little P, Annison G, Darling S, Williamson R, Camba L, Modell B. Antenatal diagnosis of thalassaemia, a model for the antenatal diagnosis of monogenic disorders, using molecular analysis of linked DNA polymorphisms. Nature (in press).

(Accepted 18 March 1980)

ONE HUNDRED YEARS AGO M Schwartz speaks in the Archiv für Gynäkologie of an extraordinary and shocking case, in which a midwife by inconceivable violence seems to have torn away during the act of labour what she described as "the rest of the afterbirth"; but which, when examined by the physician, proved to be the whole of the uterus. The ovaries and Fallopian tubes remained in the abdomen. The uterus is preserved at Halle. The woman recovered in fifteen days, and has since enjoyed good health. Venereal desires still existed, although less pronounced, and coitus was accompanied by less obvious sensations. (British Medical fournal, 1880.) 